\title{
Performance, carcass and meat quality of ewes supplemented with magnesium oxide
}

\author{
Camila Constantino ${ }^{1}$, Edson Luis de Azambuja Ribeiro ${ }^{1}$, Ana Maria Bridi ${ }^{1}$, Marina Avena \\ Tarsitano ${ }^{1}$, Filipe Alexandre Boscaro de Castro ${ }^{1}$, Francisco Fernandes Júnior ${ }^{1}$, Ivone Yurika \\ Mizubuti ${ }^{1}$, Elzânia Sales Pereira ${ }^{2}$
}

\footnotetext{
${ }^{1}$ Universidade Estadual de Londrina, Londrina, PR, Brasil.

2 Universidade Federal do Ceará, Fortaleza, CE, Brasil.
}

\begin{abstract}
The objective of this study was to evaluate the performance, the carcass and meat characteristics of ewes supplemented with magnesium oxide. Eighteen 6-year-old Santa Ines ewes were used in a completely randomized experimental design, where three levels of supplementation $(0.0,0.1$ and $0.2 \%$ magnesium oxide in the concentrate) were tested, with six replicates. Final weight, weight gain, feed intake and feed conversion were not affected by levels of magnesium supplementation. Hot and cold carcass weights showed linear increasing and quadratic responses, respectively, according to supplementation with magnesium. Carcass measurements such as length, depth, and measures of arm and leg were not affected by supplementation. Depth and width of the longissimus muscle and rib-eye area were not affected; however, marbling and ether extract increased linearly with supplementation. Water loss and color were not affected. Lipid oxidation and shear force were not affected by supplementation, while the myofibrillar fragmentation index showed a quadratic regression. There was a linear decrease in $\mathrm{pH}$ with magnesium supplementation. Supplementation with magnesium can improve carcass and meat $\mathrm{pH}$, but can act negatively by increasing the amount of marbling and ether extract of meat.
\end{abstract}

Key Words: marbling, myofibrillar fragmentation index, oxidation, production, sheep

\section{Introduction}

The meat from young animals is usually tender and with lower fat content, so it is preferred by consumers. However, in complete-cycle production systems, the culling of the ewes is necessary when there is a reduction in production efficiency of animals. The annual culling percentage of ewes ranges from 15 to $20 \%$ per year (Cavalcante and Lôbo, 2005).

The meat from culled animals is undervalued because of its sensory characteristics, such as pronounced aroma and flavor, greater amount of carcass fat and less tenderness. According to Bressan et al. (2001), sheep meat should be offered to the market in quantity and quality, increasing competitiveness with other proteins of animal origin.

The pre-slaughter stress can increase the incidence of dark, firm and dry (DFD) meat in ruminants (Apple et al., 2005). When this happens, there is a greater possibility of microbial growth, reducing the shelf life of refrigerated meat (Gardner et al., 1999). Stress activates the sympathetic nervous system by releasing catecholamines (epinephrine and norepinephrine), which are responsible for increasing respiratory rate, heart rate, body temperature and the expense of muscle glycogen.
Higher concentration of epinephrine in the blood increases the activity of calpastatin in the muscle, which may contribute to higher toughness of meat (Morgan et al., 1993).

One way to improve the quality of meat from slaughtered animals is supplementation with magnesium above the level recommended by the National Research Council (NRC, 1985). This has been shown to reduce catecholamine release (D'Souza et al., 1998), and to potentiate the effect of insulin, which facilitates the formation of muscle glycogen (Gardner et al., 2001). These changes may reduce the incidence of DFD (dark, firm and dry meat), because they are responsible for improvements in the drop of the hydrogen potential $(\mathrm{pH})$ post-mortem, which leads to a reduction in water loss, improves meat color and increases the shelf life through the stability of lipids from the membrane (D'Souza et al., 1998; Apple et al., 2001).

The present work aimed to evaluate the effects of supplementation with magnesium oxide on performance, carcass and meat quality of culled ewes.

\section{Material and Methods}

The experiment was conducted in accordance with ethical standards and approved by the Ethics Committee on 
Animal Experimentation of the Universidade Estadual de Londrina (UEL), registered under No. 58/09, and process No. 13655/2009. Eighteen Santa Inês ewes, with average age of 6 years, were used.

The experimental design adopted was completely randomized, where three levels of magnesium supplementation $(0,0.1$, and $0.2 \%)$ in the diet dry matter were tested, with six replicates. The diets were formulated to contain the same amount of nutrients $(9.3 \% \mathrm{CP}$ and $61.5 \%$ TDN), except for levels of magnesium (Table 1), and formulated to meet the requirements established by the NRC (1985), for a daily gain of $100 \mathrm{~g}$.

The observed sorghum silage composition $(\mathrm{g} / \mathrm{kg}$ of DM) was 75.4 CP, 26.6 EE, 633.2 NDF, 381.8 ADF, 598.3 TDN, and 2.04 magnesium. Magnesium was quantified according to Malavolta et al. (1992), in which, after the nitric-perchloric digestion, and preparation of the solutions, reading was done by atomic absorption spectrometry. Chemical analysis (DM, CP, EE, NDF, TDN) of the feed, leftovers and feces followed the methods of Van Soest and Weende described by Mizubuti et al. (2009).

The animals showed, at the beginning of the experiment, average weight of $50.22 \pm 5.44 \mathrm{~kg}$, and were kept in individual pens $(1.3 \times 2.0 \mathrm{~m})$ in a stall with slatted floor. After six days of adaptation, when all animals received the control

Table 1 - Proportion of ingredients in the concentrate diets and chemical composition of the concentrate and of the experimental diets

\begin{tabular}{|c|c|c|c|}
\hline \multirow{2}{*}{ Composition } & \multicolumn{3}{|c|}{ Levels of supplementation with $\mathrm{MgO}$} \\
\hline & $0 \%$ & $0.1 \%$ & $0.2 \%$ \\
\hline \multicolumn{4}{|l|}{ Concentrate ingredients (g/kg NM) } \\
\hline Corn & 868.5 & 866.9 & 865.3 \\
\hline Soybean meal & 47.1 & 47.1 & 47.0 \\
\hline Soybean oil & 37.2 & 37.1 & 37.1 \\
\hline Sodium chloride & 37.2 & 37.1 & 37.1 \\
\hline Calcium carbonate & 9.9 & 9.9 & 9.9 \\
\hline Magnesium oxide & 0.0 & 1.9 & 3.7 \\
\hline \multicolumn{4}{|l|}{ Composition of concentrate } \\
\hline Dry matter (g/kg NM) & 856.5 & 865.2 & 868.4 \\
\hline Crude protein (g/kg DM) & 113.9 & 117.4 & 119.8 \\
\hline Ether extract (g/kg DM) & 40.7 & 36.4 & 36.0 \\
\hline Crude fiber (g/kg DM) & 28.9 & 27.7 & 27.2 \\
\hline Neutral detergent fiber (g/kg DM) & 164.9 & 164.6 & 164.4 \\
\hline Acid detergent fiber (g/kg DM) & 26.5 & 26.5 & 26.4 \\
\hline Total digestible nutrients ( $\mathrm{g} / \mathrm{kg} \mathrm{DM})$ & 802.2 & 794.3 & 794.9 \\
\hline Magnesium (g/kg DM) & 10.7 & 21.1 & 31.3 \\
\hline \multicolumn{4}{|c|}{ Chemical composition of total mixed ration } \\
\hline Dry matter (g/kg NM) & 486.9 & 490.3 & 491.6 \\
\hline Crude protein (g/kg DM) & 90.8 & 92.2 & 93.1 \\
\hline Ether extract (g/kg DM) & 32.2 & 30.5 & 30.3 \\
\hline Neutral detergent fiber (g/kg DM) & 445.9 & 445.7 & 445.6 \\
\hline Acid detergent fiber (g/kg DM) & 239.7 & 239.6 & 239.6 \\
\hline Total digestible nutrients ( $\mathrm{g} / \mathrm{kg} \mathrm{DM})$ & 679.9 & 676.7 & 676.9 \\
\hline Magnesium (g/kg DM) & 16.5 & 24.9 & 31.0 \\
\hline
\end{tabular}

DM - dry matter; NM - natural matter.
$\operatorname{diet}(\mathrm{T} 1)$, the following experimental period lasted 42 days, in which the animals were subjected to the treatments: $0 \%$ oxide $(\mathrm{MgO}), 0.1 \% \mathrm{MgO}$ and $0.2 \% \mathrm{MgO}$ in concentrate.

The animals were fed twice a day ( 8.00 and 17.00 hours), and received sorghum silage and concentrate in a ratio of 60:40 (dry basis), and water ad libitum. The feed provided and the leftovers were weighed daily. A total of $10 \%$ of leftovers of the dry matter offered were allowed daily. In the last week of the experiment, feces were collected to evaluate diarrhea and chemical analysis. Weights and body condition scores (values from 1 - extremely thin, to 5 - obese) were evaluated weekly, following the method of Osorio and Osorio (2005).

The animals at the beginning of the experiment showed an average body condition score of 2 , and were slaughtered when they reached score 3 and live weight of $55 \mathrm{~kg}$. Before the slaughter, the animals went through a fasting period (solids) of 16 hours. They were transported $40 \mathrm{~km}$ to the slaughterhouse and remained in the waiting pen for 12 hours. Animals were stunned with an electric current according to the standards of humanitarian slaughter, with a Petrovina ${ }^{\circledR}$ IS 2000 (Sertãozinho, BR) equipment with two electrodes, using 350 volts and $1.3 \mathrm{amps}$ for 3 seconds. The carcasses were weighed immediately after slaughter (hot carcass weight) and after 24 hours of cooling at $2{ }^{\circ} \mathrm{C}$ (cold carcass weight). Yields were calculated as the percentages of hot and cold carcass weights in relation to body weight (Osorio and Osorio, 2005).

At slaughter, all viscera were collected, and later, renal and intraperitoneal fats were separated and weighed (Cezar and Sousa, 2007).

Evaluations for conformation score, which indicates the degree of carcass muscularity ( 1 - concave, to 6 - convex), and degree of fattening, which measures the amount of subcutaneous fat on the carcass ( 1 - absent, to 5 - abundant), were performed using photographic standards (Cañeque and Sañudo, 2000). Carcass length and chest depth, and length, perimeter and depth of leg and arm were also measured (Osorio and Osorio, 2005).

Left half carcasses were cut at the 12th rib to determine the rib-eye area, fat thickness, depth and width of the longissimus dorsi (Cezar and Sousa, 2007). Marbling was evaluated subjectively using photographic standards from the American Meat Science Association (AMSA, 2001), which are graded from 1 to 6 ( 1 - traces and 6 - abundant).

Carcasses were divided in shoulder, leg, neck and the rib-loin was divided at the junction between the spine and ribs, and this portion of the loin was then taken to the laboratory. Each portion was weighed to determine the percentage of carcass cuts. 
The portion sent to the laboratory was deboned, releasing the longissimus muscle. The muscle was divided into 6 pieces $(3 \mathrm{~cm}$ each): one for myofibrillar fragmentation index, one for lipid oxidation, two for shear force and two for sensory analysis; and two pieces $(2 \mathrm{~cm})$ : one to perform measurements of color, $\mathrm{pH}$ and water loss by pressure, and one for quantifying crude protein, moisture, ash and ether extract from meat.

Color was analyzed using a portable MINOLTA ${ }^{\circledR} \mathrm{CR}-10$ colorimeter with illuminant $\mathrm{C}$ and $8^{\circ}$ angle of inclination (Tokyo, JP) for the assessment of the components $\mathrm{L}^{*}$ (luminosity), $\mathrm{a}^{*}$ (red-green component) and $\mathrm{b}^{*}$ (yellowblue component), which were expressed in the CIELAB color system. With these values, the hue angle $\left(h^{*}\right)$ was calculated using equation $\mathrm{h}^{*}=\tan ^{-1}\left(\mathrm{~b}^{*} / \mathrm{a}^{*}\right)$ and the saturation index or chroma $\left(\mathrm{c}^{*}\right)$ using the equation $\mathrm{c}^{*}=$ $(\mathrm{a} * 2+\mathrm{b} * 2) 0.5$.

Water loss, which assesses the water-holding capacity (WHC), was evaluated by pressure on filter paper (Barbut, 1996). The $\mathrm{pH}$ was verified using a portable potentiometer with electrode insertion TESTO ${ }^{\circledR} 205$ (Lenzkirch, DE). Other samples were packaged and frozen. The left shoulder was also frozen for later dissection to obtain the proportion of bone, muscle and fat.

The shear force was objectively measured using the Texture Analyser TA.TX-2 (Godalming, UK), with shear blade $3 \mathrm{~mm}$ probe. For obtaining the samples, a cylindrical steel sampler was used. Two steaks per animal were used; they were roasted until the internal temperature reached $71{ }^{\circ} \mathrm{C}$. From each steak, three sub-samples of approximately $1.25 \mathrm{~cm}$ thick and $2.5 \mathrm{~cm}$ height were obtained, and each sub-sample was cut once, yielding a total of six readings per animal (Whipple et al., 1990).

The myofibrillar fragmentation index was evaluated by the method proposed by Culler et al. (1978). The analysis of the lipid oxidation index was done by the Indicator of Acid Reactive Substances 2-thiobarbituric (TBARS) method (Tarladgis et al., 1964). The centesimal analysis to quantify dry matter, ash, protein and fat in the muscle was performed according to the methodology cited by Mizubuti et al. (2009).
Panelists were trained for sensory analysis to identify odor, tenderness and juiciness in beef. Sensory analysis was performed using a structured scale according to the methodology proposed by ABNT (1993). Eleven trained judges evaluated the odor intensity ( 1 - extremely intense to 5 - none), characterization of odor (fresh meat/chilled meat/fruity/matured/rancidity and reheated), tenderness ( 1 - very tough to 7 - very tender), juiciness ( 1 - none to 5 high) and global acceptability (1 - extremely unacceptable to 9 - extremely acceptable) of the sample.

Each tester received two samples, one from the control treatment and the other from the treatment supplemented with $0.2 \% \mathrm{MgO}$ (the biggest challenge), a glass of water and salt water crackers for cleansing up and rinsing the mouth, and a container with coffee powder, for cleaning up the smell.

The data were subjected to analysis of variance and polynomial derivation according to the level of supplementation with magnesium oxide. Pearson correlation coefficients were also calculated. For the data from sensory analysis, the Tukey test was performed. All analyses were conducted using SAS (Statistical Analysis System, version 9.2), assuming the significance level of $10 \%$.

\section{Results and Discussion}

The average daily weight gain, final weight, dry matter intake and feed conversion were not affected by supplementation with magnesium (Table 2). The same was observed by Apple et al. (2000), who worked with lambs fed different sources of magnesium, and Gardner et al. (2001), who evaluated three levels of supplementation with magnesium oxide. François (2009), working with termination of ewes, observed gain values of $140 \mathrm{~g}$ per day, slightly lower when compared with lambs. Gardner et al. (2001) also found no differences in weight gain.

Excess magnesium can cause osmotic diarrhea, as observed by Chester-Jones et al. (1989). However this increase in passage rate did not cause a significant increase in dry matter intake. The consumption of nutrients (crude

Table 2 - Means for performance parameters of ewes supplemented with different amounts of magnesium oxide

\begin{tabular}{|c|c|c|c|c|c|c|}
\hline \multirow{2}{*}{ Performance parameters } & \multicolumn{3}{|c|}{ Levels of supplementation with $\mathrm{MgO}$} & \multirow{2}{*}{$\mathrm{R}$} & \multirow{2}{*}{$\mathrm{CV}$} & \multirow{2}{*}{ P-value } \\
\hline & $0 \%$ & $0.1 \%$ & $0.2 \%$ & & & \\
\hline Initial weight (kg) & 50.22 & 50.43 & 51.37 & ns & 0.10 & 0.9277 \\
\hline Final weight (kg) & 55.18 & 55.88 & 56.23 & ns & 0.12 & 0.9646 \\
\hline Average daily gain $(\mathrm{kg})$ & 0.12 & 0.13 & 0.11 & ns & 0.42 & 0.8820 \\
\hline Feed conversion & 9.67 & 9.38 & 12.09 & ns & 0.32 & 0.3442 \\
\hline Daily dry matter intake (kg) & 1.16 & 1.22 & 1.33 & ns & 0.17 & 0.3471 \\
\hline
\end{tabular}

ns - not significant $(\mathrm{P}>0.10)$; $\mathrm{CV}$ - coefficient of variation; $\mathrm{R}$ - regression. 
protein, ether extract, ash, acid detergent fiber and neutral detergent fiber) were not affected $(\mathrm{P}>0.10)$.

The hot carcass yield (Table 3 ) showed a linear increase $(\mathrm{P}<0.10)$ according to the level of supplementation. This difference may have occurred due to diarrhea in the animals receiving supplementation, leading to increased gastric emptying pre-slaughter. These data are contradictory to other experiments (Zinn et al., 1996; Apple et al., 2005), who found no change in yield.

According to D'Souza et al. (1998) magnesium supplementation above the recommended level reduces the concentration of catecholamines and the effects of stress pre-slaughter. These factors contribute to a gradual decrease of $\mathrm{pH}$, ensuring stability of the plasma membrane and resulting in higher water-holding capacity (WHC).

A linear regression was expected for cold carcass yield, due to the higher water-holding capacity; however, quadratic regression was observed $(\mathrm{P}<0.10)$, but the two supplement treatments, $0.1 \%$ and $0.2 \%$, had very similar averages: 42.99 and $42.18 \mathrm{~kg} / 100 \mathrm{~kg}$ of carcass respectively, while for the control $(0 \% \mathrm{MgO})$ the average was $40.55 \mathrm{~kg} /$ $100 \mathrm{~kg}$ of carcass. Other factors could also alter the cold carcass yield, as the increase in subcutaneous fat, which acts as a protection against the cold, reducing the cooling loss and increasing the cold carcass yield. However, none of these factors was affected by supplementation with magnesium.

Averages for renal and intraperitoneal fat weights were not affected by supplementation with magnesium. Their values were 0.707 and $2.240 \mathrm{~kg}$ for the treatment $0 \% \mathrm{MgO} ; 0.547$ and $2.130 \mathrm{~kg}$ for $0.1 \% \mathrm{MgO}$; and 0.788 and $2.858 \mathrm{~kg}$ for $0.2 \% \mathrm{MgO}$, respectively. Ramirez et al. (1998) found that supplementation with $0.25 \%$ magnesium reduced the pelvic fat weight, liver and heart compared with supplementation with 0.19 and $0.32 \%$.

The subjective evaluation of conformation $(\mathrm{P}>0.10)$ indicated that all animals were with the standard 3 (rectilinear carcasses with good muscle coverage), and for fattening $(\mathrm{P}>0.10)$, animals were also standard 3 (good fat cover with small amounts of apparent muscle). Watson et al. (1998) and Apple et al. (2000) also did not find effect of supplementation on these carcass traits.

Measurements such as carcass length and chest depth, and measures of arm and leg were not affected by magnesium supplementation $(\mathrm{P}>0.10)$, probably because the animals were adults and the experiment did not contemplate the growth phase, but the finishing phase (Table 3 ).

The measures made on the longissimus dorsi muscle, depth and width of the muscle, fat thickness and rib-eye area did not differ between treatments $(\mathrm{P}>0.10)$.

Table 3 - Averages for carcass parameters of ewes supplemented with different amounts of magnesium oxide

\begin{tabular}{|c|c|c|c|c|c|c|}
\hline \multirow{2}{*}{ Carcass parameters } & \multicolumn{3}{|c|}{ Levels of supplementation with $\mathrm{MgO}$} & \multirow{2}{*}{$\mathrm{R}$} & \multirow{2}{*}{$\mathrm{CV}$} & \multirow{2}{*}{ P-value } \\
\hline & $0 \%$ & $0.1 \%$ & $0.2 \%$ & & & \\
\hline Hot carcass weight $(\mathrm{kg})$ & 23.06 & 24.61 & 24.5 & $\mathrm{~ns}$ & 0.14 & 0.6942 \\
\hline Hot carcass yield ( $\mathrm{kg} / 100 \mathrm{~kg}$ of carcass) & 41.63 & 44.06 & 43.48 & $\mathrm{~L}^{1}$ & 0.04 & 0.0736 \\
\hline Cold carcass weight $(\mathrm{kg})$ & 22.46 & 24.02 & 22.88 & ns & 0.14 & 0.7409 \\
\hline Cold carcass yield ( $\mathrm{kg} / 100 \mathrm{~kg}$ of carcass) & 40.55 & 42.99 & 42.18 & $\mathrm{Q}^{2}$ & 0.04 & 0.0890 \\
\hline Cooling loss ( $\mathrm{kg} / 100 \mathrm{~kg}$ of carcass $)$ & 2.58 & 2.43 & 2.58 & ns & 0.21 & 0.8510 \\
\hline Renal fat $(\mathrm{kg})$ & 0.71 & 0.55 & 0.79 & ns & 0.46 & 0.4270 \\
\hline Intraperitoneal fat $(\mathrm{kg})$ & 2.24 & 2.13 & 2.86 & $\mathrm{~ns}$ & 0.33 & 0.2713 \\
\hline Conformation & 3.00 & 3.00 & 3.16 & ns & 0.22 & 0.8861 \\
\hline Finish & 3.16 & 3.5 & 3.33 & ns & 0.14 & 0.5207 \\
\hline Carcass length (cm) & 70.50 & 71.08 & 70.67 & ns & 0.03 & 0.9239 \\
\hline Chest depth (cm) & 31.33 & 31.92 & 32.83 & ns & 0.03 & 0.6455 \\
\hline Leg length $(\mathrm{cm})$ & 42.00 & 41.00 & 41.50 & ns & 0.05 & 0.7809 \\
\hline Leg perimeter $(\mathrm{cm})$ & 45.50 & 44.67 & 44.50 & ns & 0.04 & 0.6763 \\
\hline Leg depth $(\mathrm{cm})$ & 15.43 & 15.48 & 15.38 & ns & 0.05 & 0.9813 \\
\hline Arm length $(\mathrm{cm})$ & 22.00 & 21.67 & 22.00 & $\mathrm{~ns}$ & 0.05 & 0.8777 \\
\hline Arm perimeter $(\mathrm{cm})$ & 18.50 & 19.33 & 18.17 & ns & 0.08 & 0.4232 \\
\hline Arm depth $(\mathrm{cm})$ & 6.57 & 6.67 & 6.43 & ns & 0.07 & 0.7381 \\
\hline Muscle depth (mm) & 50.15 & 53.69 & 52.36 & $\mathrm{~ns}$ & 0.10 & 0.5625 \\
\hline Muscle width (mm) & 29.37 & 29.29 & 29.72 & ns & 0.16 & 0.9866 \\
\hline Marbling & 2.17 & 2.50 & 3.33 & $\mathrm{~L}^{3}$ & 0.33 & 0.0936 \\
\hline Fat thickness (mm) & 4.54 & 5.82 & 4.48 & ns & 0.41 & 0.4594 \\
\hline Rib-eye area $\left(\mathrm{cm}^{2}\right)$ & 13.08 & 13.50 & 13.12 & ns & 0.23 & 0.9684 \\
\hline Bone proportion ( $\mathrm{kg} / 100 \mathrm{~kg}$ of shoulder) & 21.52 & 20.69 & 19.16 & ns & 0.17 & 0.5216 \\
\hline Muscle proportion $(\mathrm{kg} / 100 \mathrm{~kg}$ of shoulder) & 62.80 & 59.55 & 60.54 & ns & 0.07 & 0.4574 \\
\hline Fat proportion (kg/100 kg of shoulder) & 15.66 & 19.74 & 20.27 & ns & 0.34 & 0.4086 \\
\hline
\end{tabular}

ns - not significant $(\mathrm{P}>0.10)$; L - linear; $\mathrm{Q}$ - quadratic; $\mathrm{CV}$ - coefficient of variation; $\mathrm{R}$ - regression.

${ }^{1} \hat{y}=42.12+9.26 x\left(r^{2}=0.53\right)$.

$2 \hat{y}=40.55+40.63 x-162.38 x^{2}\left(r^{2}=0.29\right)$.

${ }^{3} \hat{y}=2.08+5.83 \times\left(r^{2}=0.94\right)$. 
Apple et al. (2000) and Coffey and Brazle (1995) also observed no difference in rib-eye area and fat thickness in lambs and steers supplemented with magnesium.

The left shoulder was dissected to determine the amounts of fat, bone and muscle. The observed averages were $20.47 \mathrm{~kg} / 100 \mathrm{~kg}$ of shoulder for bone, $18.56 \mathrm{~kg} / 100 \mathrm{~kg}$ of shoulder for fat and $60.97 \mathrm{~kg} / 100 \mathrm{~kg}$ of shoulder for muscle $(\mathrm{P}>0.10)$. These values differ slightly from those found by Pinheiro et al. (2007), probably due to breed differences. The authors found $15.39 \%$ for bone, $26.68 \%$ for fat and $57.64 \%$ for muscle in the shoulder of culled Ile de France $\times$ Ideal ewes.

Marbling (Table 3) and ether extract (Table 4) showed linear increases with magnesium supplementation $(\mathrm{P}<0.10)$.

Apple et al. (2000) observed increased values of flank streaking, which indicates more intramuscular fat dispersed in the rectus abdominales with the increase in magnesium supplementation. Coffey and Brazle (1995) observed increases in marbling in steers, which resulted in an increased score in the USDA carcass quality grade. Murrey et al. (1990) observed that supplementation with bentonite produced a higher concentration of acetate and lower propionate, acetate being the major volatile fatty acid for lipogenesis, causing higher marbling and ether extract contents.

However Coffey et al. (2000) observed that the inclusion of mica reduced the production of acetate, which, according to Apple et al. (2000), indicates that each source of magnesium should have an impact on the production of volatile fatty acids.

There was a linear reduction $(\mathrm{P}<0.10)$ in the amount of mineral matter in the muscle, as the amount of magnesium increased in the diet (Table 4). The contents of ash in the meat were similar to those found by Ribeiro et al. (2010), who worked with sheep from different genetic groups.

Magnesium in excess can lead to formation of magnesium phosphate, or magnesium can fix to colloidal particles of insoluble aluminum and be excreted in feces (Moraes, 2001). The formation of these complexes may have caused the reduction in the amount of ash in muscle, in which the loss of minerals in feces increased as the the inclusion of magnesium was elevated, thereby reducing the amount to be deposited in the muscle. Crude protein and moisture were not affected by supplementation.

The average yield of the cuts was: $7.70 \mathrm{~kg} / 100 \mathrm{~kg}$ of carcass for neck, $30.75 \mathrm{~kg} / 100 \mathrm{~kg}$ of carcass for leg, 17.85 $\mathrm{kg} / 100 \mathrm{~kg}$ of carcass for shoulder and $43.70 \mathrm{~kg} / 100 \mathrm{~kg}$ of carcass for rib-loin. There was no effect of magnesium supplementation on yields $(\mathrm{P}>0.10)$. The values were close to those found by Francois (2009): $8.59 \%$ for neck, 32.08\% for leg, $17.91 \%$ for shoulder and $40.76 \%$ for rib-loin, in culled Texel $\times$ Ile de France ewes.

The water loss by pressure, and cooking loss (Table 5) were not affected by supplementation, but the defrosting loss showed an increase $(\mathrm{P}<0.10)$ with increasing levels of magnesium (Table 5). According to D'Souza et al. (1998) supplementation with magnesium increases the waterholding capacity. During the freezing process, ice crystals were formed and the cell membrane ruptured, causing a higher cell leakage and defrosting loss.

The meat $\mathrm{pH}$ (Table 5) decreased $(\mathrm{P}<0.10)$ with increasing inclusion of magnesium in the diet. Gardner et al. (2001) observed $21 \%$ more glycogen post-mortem in animals supplemented with $\mathrm{MgO}$ than in the control group. This may have caused the decrease in $\mathrm{pH}$ observed with $\mathrm{MgO}$ supplementation. Values found for the three treatments were within normal limit (5.6 to 5.8), which, according to Gonçalves et al. (2004), confirms the fact that lambs rarely present problems related to $\mathrm{pH}$, like the occurrence of DFD meat.

The myofibrillar fragmentation index showed a quadratic regression $(\mathrm{P}<0.1)$, in which the lowest value was from animals that received $0.1 \% \mathrm{MgO}$. The index correlates the fragmentation of myofibrils with meat tenderness. The turbidity increases proportionately with the number of fragments, and hence the tenderness of meat. High values of myofibrilar fragmentation index (close to 100) indicate major disruption of myofibril structure, so it is an indicator of tender muscles.

Table 4 - Averages for the composition of the longissimus dorsi of ewes supplemented with different amounts of magnesium oxide

\begin{tabular}{|c|c|c|c|c|c|c|}
\hline \multirow{2}{*}{ Component } & \multicolumn{3}{|c|}{ Levels of supplementation with $\mathrm{MgO}$} & \multirow{2}{*}{$\mathrm{R}$} & \multirow{2}{*}{$\mathrm{CV}$} & \multirow{2}{*}{ P-value } \\
\hline & $0 \%$ & $0.1 \%$ & $0.2 \%$ & & & \\
\hline Crude protein ( $\mathrm{g} / 100 \mathrm{~g}$ of meat) & 27.78 & 24.67 & 27.06 & ns & 0.06 & 0.4082 \\
\hline Ether extract (g/100 g of meat) & 6.16 & 6.89 & 9.99 & $\mathrm{~L}^{1}$ & 0.53 & 0.0540 \\
\hline Ash (g/100 g of meat) & 3.37 & 3.31 & 2.97 & $\mathrm{~L}^{2}$ & 0.09 & 0.0886 \\
\hline
\end{tabular}

ns - not significant $(\mathrm{P}>0.10)$; L - linear; CV - coefficient of variation; $\mathrm{R}$ - regression.

${ }^{1} \hat{\mathrm{y}}=12.16+2.07 \mathrm{x}\left(\mathrm{r}^{2}=0.82\right)$.

$2 \hat{y}=3.40-1.95 x\left(r^{2}=0.86\right)$. 
Table 5 - Means for parameters of the longissimus dorsi of ewes supplemented with different amounts of magnesium oxide

\begin{tabular}{|c|c|c|c|c|c|c|}
\hline \multirow{2}{*}{ Meat parameters } & \multicolumn{3}{|c|}{ Levels of supplementation with $\mathrm{MgO}$} & \multirow{2}{*}{$\mathrm{R}$} & \multirow{2}{*}{$\mathrm{CV}$} & \multirow{2}{*}{ P-value } \\
\hline & $0 \%$ & $0.1 \%$ & $0.2 \%$ & & & \\
\hline Water loss by pressure $(\mathrm{g} / 100 \mathrm{~g})$ & 23.61 & 29.39 & 27.67 & ns & 0.21 & 0.2376 \\
\hline Defrosting loss $(\mathrm{g} / 100 \mathrm{~g})$ & 4.39 & 8.11 & 7.28 & $\mathrm{~L}^{1}$ & 0.40 & 0.0728 \\
\hline $\mathrm{pH}$ & 5.65 & 5.54 & 5.53 & $\mathrm{~L}^{2}$ & 0.01 & 0.0629 \\
\hline Shear force $(\mathrm{kgF})$ & 3.10 & 3.10 & 3.64 & ns & 0.20 & 0.2960 \\
\hline Myofibrillar fragmentation index & 0.94 & 0.90 & 1.00 & $Q^{3}$ & 0.07 & 0.0624 \\
\hline $\mathrm{a}^{*}$ (green-red component) & 18.66 & 19.47 & 20.07 & ns & 0.09 & 0.4151 \\
\hline b* (blue-yellow component) & 6.89 & 7.27 & 7.37 & ns & 0.10 & 0.5492 \\
\hline $\mathrm{c}^{*}$ (chroma) & 19.89 & 20.79 & 21.39 & ns & 0.08 & 0.3775 \\
\hline $\mathrm{h}^{*}\left({ }^{\circ}\right)$ (hue) & 20.26 & 20.60 & 20.19 & ns & 0.10 & 0.9356 \\
\hline
\end{tabular}

ns - not significant $(\mathrm{P}>0.10)$; $\mathrm{CV}$ - coefficient of variation; $\mathrm{L}$ - linear; $\mathrm{R}$ - regression.

${ }^{1} \hat{y}=14.45+5.15 x\left(r^{2}=0.54\right)$

$2 \hat{y}=5.63-0.58 \times\left(r^{2}=0.77\right)$.

$3 \hat{y}=94.13-114.37 \times 730.61 x^{2}+\left(r^{2}=0.29\right)$.

Averages, as close as those found in this experiment (91.1), did not show a real variation in tenderness between treatments, since there was no difference $(\mathrm{P}>0.10)$ in shear force. Values of $3.28 \mathrm{kgF}$ for shear force and 0.94 for fragmentation index indicate an extremely tender meat, which was not expected for culled ewes, with 6 years of age. In the sensory analysis, panelists also found no differences for tenderness.

The majority of studies with magnesium supplementation found no effect on meat tenderness (Lowe et al., 2002; Apple et al., 2005); however, Apple et al. (1999) and Apple et al. (2000), working with sheep, observed that supplementation with mica increased the shear force.

The high values for lipid oxidation were probably because the analysis was performed in samples frozen for six months. This parameter was not influenced by supplementation with magnesium. Conversely, Apple et al. (2001) found that magnesium supplementation reduced lipid oxidation, since it can capture free radicals, responsible for initiating the oxidation process.

The meat color components, $\mathrm{L}^{*}, \mathrm{a}^{*}, \mathrm{~b}^{*}, \mathrm{c}^{*}$ and $\mathrm{h}^{*}$ were not affected $(\mathrm{P}>0.10)$ by supplementation with magnesium. The same was observed by Bass et al. (2010), who also found no effect indicating that magnesium reduces pre-slaughter stress in cattle. Apple et al. (2000) also did not see any effect on meat color of supplemented lambs. However, Apple et al. (2001) observed a quadratic effect for the components $a^{*}, b^{*}$ and $\mathrm{c}^{*}$ for pigs supplemented with mica.

In the sensory evaluation with a trained panel (Table 6), no significant differences were found $(\mathrm{P}>0.10)$ for any parameter. The meat was evaluated as slightly tender, having moderate odor, moderate juiciness, and moderate acceptability.
Panelists also evaluated the characterization of the odor, where $27 \%$ of the control and $82 \%$ of the supplemented samples were characterized as having the odor of fresh meat. For the control treatment, rancid and reheated odors were also found. These two odors were not found in meat from supplemented animals. This result indicates that supplementation with magnesium possibly masks the animal odor present in the meat from culled ewes.

There was a positive correlation between hot carcass weight and yield (0.61) and cold carcass weight and yield (0.61) (Table 7). François (2009) observed no correlation between these traits when finishing ewes on pasture. Weights of hot and cold carcass showed positive correlation with the perimeter and depth of arm and leg, weights of the cuts and rib-eye area.

Weights of hot and cold carcass also had positive correlations with fat weight and negative with muscle weight. The finishing fat thickness also showed a negative correlation with the amount of muscle in the shoulder.

These results showed that with higher carcass weights, the proportion of fat relative to muscle also increases. Cooling loss showed no correlation with fat thickness, but it showed correlation (0.63) with cold carcass yield; in other words, carcasses with higher fat thickness had

Table 6 - Sensory evaluation of the longissimus dorsi of ewes supplemented with different amounts of magnesium oxide

\begin{tabular}{lccc}
\hline \multirow{2}{*}{ Parameters } & \multicolumn{2}{c}{ Levels of supplementation with MgO } & \multirow{2}{*}{ P-value } \\
\cline { 2 - 3 } & $0 \%$ & $0.2 \%$ & \\
\hline Odor intensity & 2.91 & 3.36 & 0.3367 \\
Tenderness & 5.18 & 5.73 & 0.3505 \\
Juiciness & 4.00 & 4.00 & 0.8287 \\
Overall acceptability & 6.73 & 7.36 & 0.2446 \\
\hline (P>0.10). & & &
\end{tabular}




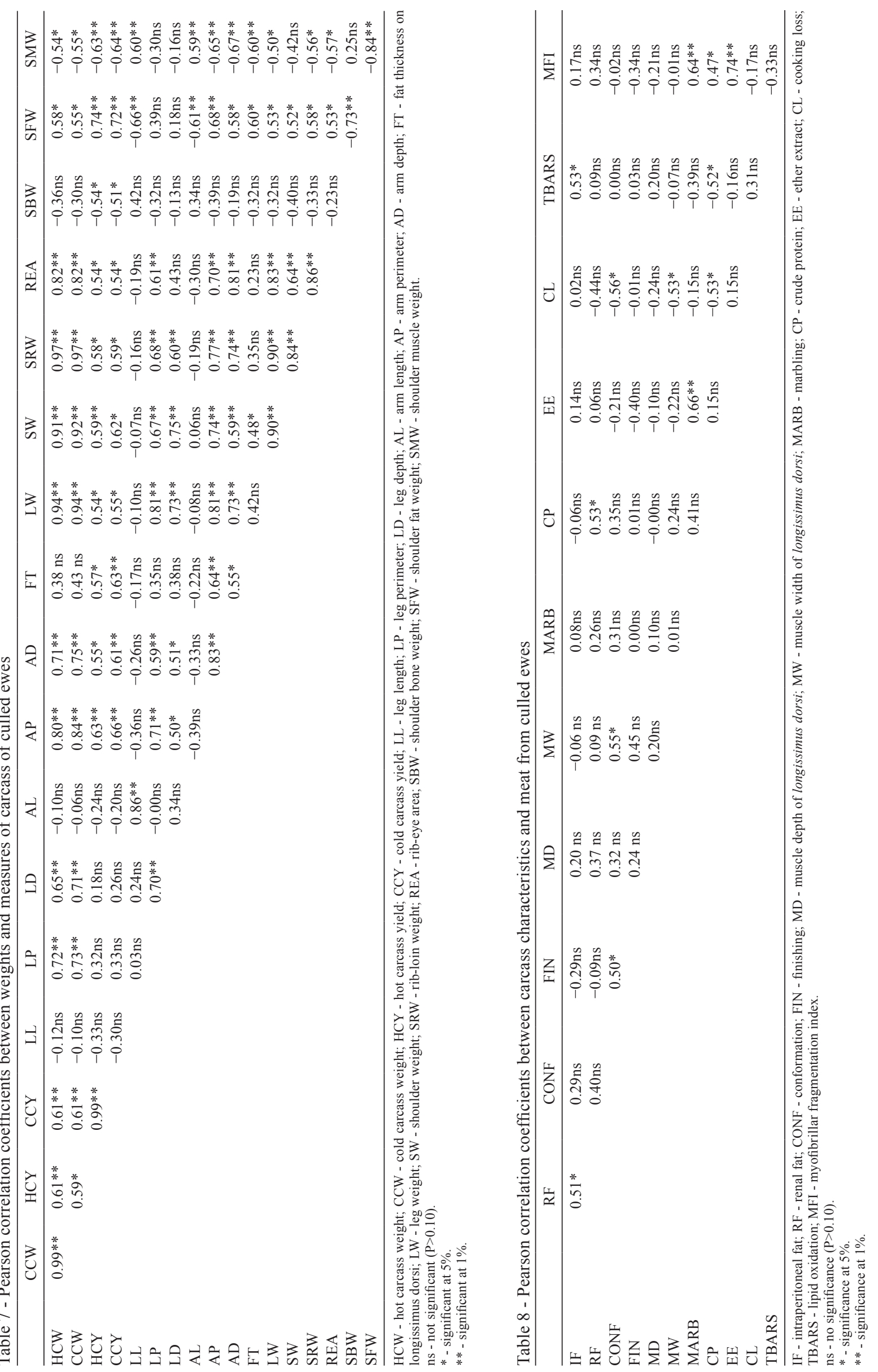

R. Bras. Zootec., v.43, n.1, p.27-35, 2014 
higher cold carcass yields. François (2009) observed no correlation between fat thickness and carcass weight. Cunha et al. (2000) observed that the fat thickness is more influenced by slaughter weight and carcass weight than by genotype.

Cold carcass yield was correlated with shoulder bone weight $(-0.51)$, shoulder fat weight $(0.72)$ and weight of muscle in the shoulder $(-0.64)$, indicating that as the cold carcass yield increases, the proportion of bone and muscle reduce, while the proportion of fat in the carcass increases. The increase in limb length indicates a negative correlation with the amount of fat and positive with the amount of muscle in the shoulder. In contrast, the perimeter and depth of members indicated the opposite: positive correlations with the amount of fat and negative with the amount of muscle in the shoulder.

The amount of intraperitoneal fat in the carcass of culled ewes presented positive correlation (0.53) with the rate of lipid oxidation (Table 8), that is, the oxidation of the meat increases with the amount of fat in the carcass cavity.

No correlation was observed between the degree of carcass fattening and the quantity of marbling. François (2009) also observed no correlation between the fattening and marbling in the carcass of culling animals.

Carcass conformation was correlated $(0.55)$ with the width of the longissimus dorsi, and negatively correlated with cooking loss. Negative correlation of the width of the muscle with cooking loss was also observed, that is, meat cooking loss is reduced when the degree of carcass muscularity increases.

The marbling of the longissimus dorsi showed correlation with the amount of lipids in the meat (0.66), and correlation (0.64) with the myofibril fragmentation index of the meat, indicating that the muscle tenderness is directly proportional to the amount of marbling.

\section{Conclusions}

Supplementation with magnesium does not affect the performance of ewes, and has positive effects on some characteristics of the carcass such as carcass yield. Magnesium has a negative effect, increasing the marbling and ether extract of the meat.

\section{Acknowledgments}

The authors thank Conselho Nacional de Desenvolvimento Científico e Tecnológico and Fundação Araucária.

\section{References}

ABNT - Associação Brasileira de Normas Técnicas. 1993. NBR 12994. Métodos de análise sensorial dos alimentos - classificação. ABNT, Rio de Janeiro.

AMSA - American Meat Science Association. 2001. Handbook meat evaluation. Champaign, IL, USA.

Apple, J.; Watson, B.; Coffey, K. and Kegley, B. 1999. Comparison of magnesium sources on muscle color and tenderness of finishing sheep. Arkansas Animal Science Department Report 470:185-188.

Apple, J. K.; Watson, H. B.; Coffey, K. P.; Kegley, E. B. and Rakes, L. K. 2000. Comparison of different magnesium sources on lamb muscle quality. Meat Science 55:443-449.

Apple, J. K.; Davis, J. R.; Rakes, L. K.; Maxwell, C. V.; Stivarius, M. R. and Pohlman, F. W. 2001. Effects of dietary magnesium and duration of refrigerated storage on the quality of vacuumpackaged, boneless pork loins. Meat Science 57:43-53.

Apple, J. K.; Kegley, E. B.; Maxwell Jr., C. V.; Rakes, L. K.; Galloway, D. and Wistuba, T. J. 2005. Effects of dietary magnesium and shortduration transportation in stress response, postmortem muscle metabolism, and meat quality of finishing swine. Journal of Animal Science 83:1633-1645.

Barbut, S. 1996. Estimates and detection of the PSE problem in young turkey breast meat. Canadian Journal of Animal Science 76:455-457.

Bass, P. D.; Engle, T. E.; Belk, K. E.; Chapman, P. L.; Archibeque, S. L.; Smith, G. C. and Tatum, J. D. 2010. Effects of sex and short-term magnesium supplementation on stress responses and longissimus muscle quality characteristics of crossbred cattle. Journal of Animal Science 88:349-360.

Bressan, M. C.; Prado, O. V.; Pérez, J. R. O.; Lemos, A. L. S. C. and Bonagurio, S. 2001. Efeito do peso ao abate de cordeiros Santa Inês e Bergamácia sobre as características físico-químicas da carne. Ciência e Tecnologia de Alimentos 21:293-303.

Cañeque, V. and Sañudo, C. 2000. Metodologia para el estúdio de la calidad de la canal y de la carne em ruminantes. INIA, Madrid.

Cavalcante, A. C. R. and Lôbo, R. N. B. 2005. Sistema de produção de caprinos e ovinos de corte para o nordeste brasileiro. Embrapa Caprinos e Ovinos, Sobral. Available at: <http://sistemasdeproducao. cnptia.embrapa.br/FontesHTML/CaprinoseOvinosdeCorte/Caprinos OvinosCorteNEBrasil/manejoprodutivo.htm\#subtitulo3> Accessed on: Apr. 28, 2010.

Cezar, M. F. and Sousa, W. H. 2007. Carcaças ovinas e caprinas: obtenção, avaliação e classificação. Agropecuária Tropical, Uberaba.

Chester-Jones, H.; Fontenot, J. P.; Veit, H. P. and Webb Jr., K. E. 1989. Physiological effects of feeding high levels of magnesium to sheep. Journal of Animal Science 67:1070-1081.

Coffey, K. P. and Brazle, F. K. 1995. Performance by finishing steers offered magnesium-mica in the feedlot ration. Report of Progress $733: 15-19$.

Coffey, K. P.; Nagaraja, T. G.; Towne, E. G.; Brazle, F. K. and Moyer, J. L. 2000. Digestibility of prairie hay diets supplemented with different levels of magnesium-mica by beef heifers. Journal of Animal Science 78:718-725.

Culler, R. D.; Parrish Jr., F. C.; Smith, G. C. and Cross, H. R. 1978. Relationship of myofibril fragmentation index to certain chemical, physical and sensory characteristics of bovine longissimus muscle. Journal of Food Science 43:1177-1180.

Cunha, E. A.; Santos, L. E. and Bueno, M. S. 2000. Utilização de carneiros de raças de corte para obtenção de cordeiros precoces para abate em plantéis produtores de lã. Revista Brasileira de Zootecnia 29:243-252.

D’Souza, D. N.; Warner, R. D.; Leury, B. J. and Dunshea, F. R. 1998. The effect of dietary magnesium aspartate supplementation on pork quality. Journal of Animal Science 76:104-109.

François, P. 2009. Desempenho, características de carcaça e a utilização da carne de ovelhas de descarte terminadas em pastagem cultivada na elaboração de embutido fermentado. Dissertação (Msc.). Universidade Federal de Santa Maria, Santa Maria. 
Gardener, G. E.; Kennedy, L.; Milton, J. T. B. and Pethick, D. W. 1999. Glycogen metabolism and ultimate $\mathrm{pH}$ of muscle in Merino, first-cross, and second-cross wether lambs as affected by stress before slaughter. Australian Journal of Agricultural Research 50:175-181.

Gardner, G. E.; Jacob, R. H. and Pethick, D. W. 2001. The effect of magnesium oxide supplementation on muscle glycogen metabolism before and after exercise and at slaughter in sheep. Australian Journal Agricultural Research 52:723-729.

Gonçalves, L. A. G.; Zapata, J. F. F.; Rodrigues, M. C. P. and Borges, A. S. 2004. Efeitos do sexo e do tempo de maturação sobre a qualidade da carne ovina. Ciência e Tecnologia de Alimentos 24:459-467.

Lowe, T. E.; Peachey, B. M. and Devine, C. E. 2002. The effect of nutritional supplements on growth rate, stress responsiveness, muscle glycogen and meat tenderness on pastoral lambs. Meat Science 62:391-397.

Malavolta, E.; Vitti, G. C. and Oliveira, S. A. 1992. Avaliação do estado nutricional das plantas - princípios e aplicações. 2.ed. Potafós, Piracicaba.

Mizubuti, I. Y.; Pinto, A. P.; Pereira, E. S. and Ramos, B. M. O. 2009. Métodos laboratoriais de avaliação de alimentos para animais. EDUEL, Londrina.

Moraes, S. S. 2001. Importância da suplementação mineral para bovinos de corte. Embrapa Gado de Corte, Campo Grande. (Documentos, 114). Available at: <http://www.cnpgc.embrapa.br/ publicacoes/doc/doc114/index.html> Accessed on: Nov. 24, 2010.

Morgan, J. B.; Wheeler, T. L.; Koohmaraie, M.; Savell, J. W. and Crouse, J. D. 1993. Meat tenderness and the calpain proteolytic system in longissimus muscle of young bulls and steers. Journal of Animal Science 71:1471-1476.

Murray, P. J.; Rowe, J. B. and Aitchison, E. M. 1990. The effect of bentonite on wool growth, live weight change and rumen fermentation in sheep. Australian Journal of Experimental Agriculture 30:39-42

NRC - National Research Council. 1985. Nutrient requirements of domestic animals: Nutrient requirements of sheep. Washington, D.C.

Osório, J. C. S. and Osório, M. T. M. 2005. Produção de carne ovina: Técnicas de avaliação in vivo e na carcaça. 2.ed. Universitária PREC/UFPEL, Pelotas.

Pinheiro, R. S. B.; Silva Sobrinho, A. G.; Yamamoto, S. M. and Barbosa, J. C. 2007. Composição tecidual dos cortes da carcaça de ovinos jovens e adultos. Pesquisa Agropecuária Brasileira 42:565-571.

Ramirez, J. E.; Alvarez, E. G.; Montano, M.; Shen, Y. and Zinn, R.A. 1998. Influence of dietary magnesium level on growth- performance and metabolic responses of Holstein steers to laidlomycin propionate. Journal of Animal Science 76:1753-1759.

Ribeiro, E. L. A.; Oliveira, H. C.; Castro, F. A. B. C.; Mizubuti, I. Y.; Silva, L. D. F. and Barbora, M. A. F. 2010. Características de carcaça e carne de cordeiros mestiços de três grupos genéticos. Semina: Ciências Agrárias 31:793-802.

Tarladgis, B. G.; Pearson, A. M. and Dugan Jun, L. R. 1964. Chemistry of the 2-thiobarbituric acid test for determination of oxidative rancidity in foods: formation of the tba-malonaldehyde complex without acid-heat treatment. Journal of Food Science and Agriculture 5:602-604.

Watson, H. B.; Coffey, K. P.; Kegley, E. B. and Apple, J. K. 1998. Comparison of magnesium sources in diets of finishing lambs. Journal of Animal Science, 76(Suppl.1):359.

Whipple, G.; Koohmaraie, M.; Dikeman, M. E. and Crouse, J.D. 1990. predicting beef-longissimus tenderness from various biochemical and histological muscle traits. Journal of Animal Science 68:4193-4199.

Zinn, R. A.; Shen, Y.; Adam, C. F.; Tamayo, M. and Rosalez, J. 1996. Influence of dietary magnesium level on metabolic and growthperformance responses of feedlot cattle to laidlomycin propionate. Journal of Animal Science 74:1462-1469. 